\title{
Wisdom and Resilience Strategies as Predictors of Successful Aging
}

\section{Raquel Maria Rossi Wosiack, Andrea Varisco Dani, Victória Haas Masiero, Marcio Rafael Slaviero, Camila Koren Chiappini, Martina Dillenburg Scur, Geraldine Alves Dos Santos}

\author{
Feevale University \\ Brazil
}

\begin{abstract}
The purpose of this study was to analyze the wisdom construct and its relationship with successful aging and resilience strategies. The methodological design was quantitative and transversal. A total of 193 people, ranging in age from 60 to 79 years old, living in the city of Ivoti / Brazil participated. The instruments used were the Resilience Scale, Wisdom Scale and SOC Inventory. It was found that the wisdom and resilience variables had high scores; there was no significant difference when compared between age and sex groups. The most commonly SOC strategy used was loss selection. After analysis of the stepwise multiple linear regression for the wisdom dependent variable, the explanatory model composed the independent variables of resilience and elective selection. It is concluded that for an elderly to develop wisdom it is necessary to be associated with strategies of resilience and elective selection.
\end{abstract}

Uniterms: Wisdom. Resilience. Successful aging

\section{IIntroduction}

Wisdom is a construct known to be able to incorporate a positive dimension into people's lives and therefore, especially the elderly, since it can present itself more effectively at maturity. In addition, wisdom can be approached from a variety of perspectives: historical, philosophical, theological, and psychological. This study focuses on the psychological perspective and considers wisdom as an exceptional level of interpersonal and intrapersonal competence that implies the ability to listen, evaluate and give advice and that is used to increase one's own and others' well-being (Carr, 2007). As a multidimensional reality, wisdom considers functions such as the ability to make decisions about one's own life; helping others make decisions; manage social issues; to be able to ask questions about matters of a spiritual nature and about oneself (Sternberg, 1990).

The epigenetic model of Erikson (1998) considers wisdom as the value acquired in the eighth stage of development if it is successful. The crisis would be between the capacity to accept existence as something valuable, to be satisfied with life and disenchantment with the existential experience. It is common to say that wisdom is related to the informed and detached concern of the position of one's own life in the face of death. Furthermore, the maturation signaled by wisdom is universal and crosses cultures and socioeconomic classes.

Sternberg's theory of balance of wisdom (2004) presents wisdom as a balance between the intrapersonal, the interpersonal, and the extra personal. For Pascual-Leone (1990), good management and the use of emotions play an important role in the process of developing wisdom, being the last level of human growth. Authors like Oser, Schenker and Spychiger (1999), Ardelt (2004),Coll, Marchesi and Palácios (2004) and Staudinger (2008) also studied and researched this theme.

In this study, the orientation of the lifespan paradigm was chosen, once successful aging construct follows this same paradigm, thus having coherence in the approach used. Baltes and Staudiger (1993) report that their studies focus on common opinions about wisdom that allow the objective quantification of performance related to it. Ardelt (1997) confirms that wisdom is closely related to life satisfaction in old age, and advanced age is cited as a necessary condition, but not sufficient for wisdom to be acquired.

Baltes and Smith (2004) present seven properties that are part of the concept of wisdom: responds with excellent strategies to important and complex issues of human conduct and life meaning; represents a truly superior level of knowledge, judgment and counsel; is characterized by a knowledge with an extraordinary extent, depth, balance; it is defined in the particular knowledge about the limits of the own knowledge and in the contingencies of the reality; involves a perfect synergy of mind and character, using knowledge and virtues for the well-being of self and others; is present in innumerable human acts and actions; is also related to certain intelligence and personality factors, with scientific curiosity, creativity and reflective style in thinking. 
Research on wisdom comes in parallel with the realization that both human development and aging are processes that occur throughout the life cycle and therefore require a broader approach that fits the Baltes and Smith (1995) perspective when considering Human development as multidimensional and multidirectional, in a complex format that involves losses and gains. Thus, the authors believe that with advancing age the observed losses in the global functional capacity of intelligence can be offset by the use of more extensive knowledge structures. Alves (2011) explains that the development process occurs throughout the life cycle, with different forms in the search for life meaning and wisdom. It joins wisdom, life experience, balance between cognition and affection, and from it provides a more global knowledge of life, the relativity of the accessory and the valuation of the essential. These united elements provoke an increase in the capacity for discernment and counseling, in search of a greater sense for life and also for death (Barros, 2005).

Therefore, it is important that, with the aging process, the resilience capacity of the elderly is increased, so that adaptive behavior can be maintained, since in old age there is a greater probability of unpleasant events related to physical health, well-being and the life of loved ones. Knowing what factors are protective elements, we will be able to stimulate them, favoring the emergence of resilience and promoting successful aging.

Researchers P. Baltes and M. Baltes have developed with their interdisciplinary team at the Max Planck Institute for Human Development in Germany, studies that have given rise to a widely accepted conceptual framework for lifecycle development studies. Lifespan theory or theory of development throughout life was consolidated by the study entitled The Berlin Aging Study (BASE). From these studies the success story was consolidated and an intervention strategy called SOC - Selection, Optimization and Compensation was created (Papalia\& Feldman, 2013; Baltes\& Mayer, 2001).

The strategies for successful aging are analyzed by Baltes and Baltes (1993) in seven propositions: a) The human being needs to be aware of the lifestyle that he adopts so that the organism stays in healthy conditions; B) because of the heterogeneity of the aging process, simplistic and standardized formulas should not be created, people should understand the need to take their own actions, just as society must have the flexibility to accept them; C) there is a need for environments that enable the development of latent capacities of the elderly; D) to show the capacities that the elderly can use and its limits; E) use of resources and technology to address the deficits of the aging process; F) the aging process involves the balance between losses and gains, and, finally, the importance of the last item, g) the capacity of resilience.

Baltes and Silverberg (1995) point out that successful adjustment is correlated to the existence of social relationships networks that allow greater intimacy in conversations, reinforcing the importance of intimate connections between people, rather than broader social relations. For the authors, these closer relationships form a protective system for difficult and stressful moments.

Successful old age, according to Neri and Cachioni (1999), has three connotations. The first is associated with the conception that the individual must develop his / her individual potential to feel the physical, social and psychological well-being adequate for the individual and group parameters. The second is the stipulated concept of well-being based on the youth-based model and the third conception is based on the maintenance of the individual's competences, which can be better utilized through the mechanisms of compensation and optimization, thus the elderly may even take advantage of and improve their abilities while maintaining the sense of well-being.

However, human aging is often characterized as a time of fragility, marked by many losses. Although old age can also be a time marked by great gains, provided there is support in the area of health that guarantees quality of life. Fragility has been inadequately addressed as disability and comorbidity (Neri, Yasuda, \& Cachioni, 2004).

In this way, the ability to cope and also recover from the effects of highly demanding events on personal resources, or psychological resilience, tends to remain during old age (Baltes, 1987; Gatz, 1998). Psychological resilience is associated with the presence of self-regulation mechanisms (Bandura, 1986), among which we can mention coping strategies and self-evaluations referenced to social and temporal comparison processes (Neri, 2002; Rabelo \& Neri, 2006). In interaction with social resources, these mechanisms function as mediators of psychological well-being. Since they have been exposed to different social and personal circumstances in their life history, which have led to different health, intelligence and personality conditions, the elderly are not all the same about these mechanisms. Thus, there is a strong variability in the ways of interpreting and dealing with events that impose excessive demands on its resources, among them biological fragility (Neri \& Fortes, 2006; Aldwin \& Gilmer, 2004).

Considering all the aforementioned elements, it is important to understand that some factors promote and others obstruct wisdom and resilience. These elements may or may not lead to successful aging. Only from the knowledge of the roles that these elements play, can it be possible to design projects that promote public policies capable of fostering 
a successful aging. Thus, this article aims to analyze the wisdom construct and its relationship with successful resilience and aging strategies.

\section{METHOD}

The present study has a quantitative and transverse design, and the measurements were made in a single moment, therefore, there is no follow-up period of the individuals. The research was carried out in the municipality of Ivoti / Brazil in partnership with the Municipal Council of the Elderly and the Department of Health and Social Assistance of the Municipality of Ivoti / Brazil.

\subsection{Sample}

The sample was composed of 193 elderly people between 60 and 79 years old, of both sexes, living in the city of Ivoti / Brazil. Inclusion criteria were over 60 years of age, living in the municipality of Ivoti, not being institutionalized or hospitalized, having mental and health conditions to have independence and autonomy to participate in the study. The exclusion criteria were: to present dementia processes, fragility syndrome, to be hospitalized or institutionalized.

\subsection{Data collection instruments}

In this study evaluations of successful aging, resilience and wisdom were carried out, and we present the instruments that evaluated the described variables. Scale on Wisdom, developed by Alves (2011), provides information on how people conceive "wisdom" and the values associate with the wise person; Approaches values associated with intelligence, personality and transcendence. Three direct questions related to the three factors are associated with the scale, so that more information can be obtained and the existence of significant relations between them can be verified. The scale ranges from 1 (totally at odds) to 5 (fully agree).Resilience Scale, developed by Wagnild and Young (1993), used to measure resilience assessed by levels of positive psychosocial adaptation to major life events. The scale is composed of 24 likert-type items that range from 1 (totally disagree) to 7 (totally agree). Scores range from 24 to 168 and high values indicate high resilience. This scale was adapted by Pesce, Assis, Avanci, Santos, Malaquias, and Carvalhaes (2005) and considered relevant for Brazilian culture; SOC Inventory (Selection, Optimization, Compensation), explains the concept of successful aging. Baltes, Baltes, Freund and Lang developed it in 1999. The inventory used in this study is a reduced version of 12 items described by Freund and Baltes (2002) as more favorable and evaluates the use of SOC strategies by the elderly. Each item consists of two statements: one describing the behavior reflecting the SOC strategy and the other offering a reasonable but not SOC option. The participant must decide which of the two alternatives characterizes his behavior. Almeida, Stobäus and Resende (2013) validated this version for Brazilian culture.

\section{Results}

After the classification and data collection were performed, descriptive, comparative and multiple stepwise linear regression studies were performed. For the comparative study of means, the Mann Whitney tests, with acceptance level of 0.05were used. For the statistical study, the Statistical Pachage for the Social Sciences - SPSS - for Windows, v. 22.0.Regarding the participants age in this study, we had an average age of 67.28 years with a standard deviation of 5.65 years. The minimum and maximum stipulated in the sample definition were 60 and 79 years. The age groups were divided into four categories: 60 to 64 years (38.1\%), 65 to 69 years $(27.5 \%), 70$ to 74 years $(17.6 \%)$ and 75 to 79 years $(16.6 \% \%)$. We can identify the predominance of the initial bands. In this sample, we had $28.9 \%$ of males and $71.1 \%$ of females, identifying the presence of a greater number of females, a factor that is widely discussed in the literature on the feminization of old age. In addition, the variables wisdom, resilience and SOC were not significantly different when compared to the variables gender and age group; it is divided between 60 and 69 years and between 70 and 79 years of age (Mann Whitney test).

Table 1. Characterizationofparticipants

\begin{tabular}{|c|c|c|c|c|c|c|}
\hline & $\begin{array}{l}60-69 \\
(n=127\end{array}$ & & $\begin{array}{l}70-79 \\
(n=66)\end{array}$ & & $\begin{array}{l}\text { Total } \\
(n=193)\end{array}$ & $P$ \\
\hline & $\begin{array}{l}\text { Male } \\
(\mathrm{n}=36)\end{array}$ & $\begin{array}{l}\text { Female } \\
(n=91)\end{array}$ & $\begin{array}{l}\text { Male } \\
(n=20)\end{array}$ & $\begin{array}{l}\text { Female } \\
(n=46)\end{array}$ & & \\
\hline \multirow[t]{2}{*}{ Wisdom } & 86,33 & 85,78 & 82,00 & 84,35 & 85,18 & $0,134 *$ \\
\hline & $\pm 9,00$ & $\pm 7,77$ & $\pm 12,58$ & $\pm 8,25$ & $\pm 8,68$ & $0,709 * *$ \\
\hline \multirow[t]{2}{*}{ Resilience } & 144,42 & 142,68 & 138,26 & 143,98 & 142,85 & $0,974 *$ \\
\hline & $\pm 10,21$ & $\pm 12,75$ & $\pm 23,60$ & $\pm 13,08$ & $\pm 13,80$ & $0,814 * *$ \\
\hline \multirow[t]{2}{*}{ SOC } & 7,89 & 7,67 & 7,63 & 7,15 & 7,59 & $0,130 *$ \\
\hline & $\pm 2,59$ & $\pm 2,18$ & $\pm 2,24$ & $\pm 2,07$ & $\pm 2,24$ & $0,352 * *$ \\
\hline
\end{tabular}

* $p$ variable age group $* * p$ variablegender 
Table 2 presents the facets of the wisdom variable, demonstrating that all results are high, but the best performance lies in the personality facet.

Table 2 - Descriptive analysis of the factors of the wisdom variable

\begin{tabular}{lllll}
\hline & Min. & Máx. & Mean & Sd. \\
\hline Wisdom - Knowledge & 1 & 4 & 3,71 &, 726 \\
Wisdom-Happiness & 1 & 4 & 3,92 &, 436 \\
Wisdom - Religiouspractice & 1 & 4 & 3,92 &, 436 \\
Wisdom - Inteligence & 2 & 5 & 4,31 &, 557 \\
Wisdom - Transcendence & 2 & 5 & 4,31 &, 611 \\
Wisdom - Personality & 3 & 5 & 4,36 &, 486 \\
\hline
\end{tabular}

Analyzing the resilience variable, it can be observed that $90.7 \%$ of the sample presented a high level of resilience, $8.8 \%$ moderate and $0.5 \%$ low. Wagnild (2009) and Wagnild and Young (1993) through exploratory factorial procedures identified the existence of only two factors of resilience, which they called "Personal Competence" and "Self / Life Acceptance", which obtained alpha consistency of Cronbach higher than 0.80. This study was applied to 810 elderly people. In the present study, we maintained this subdivision, precisely because we are working with the same population chosen by these authors. The first factor: personal competence expresses self-confidence, independence, determination, mastery and perseverance. The second factor: Self/Life Acceptance expresses adaptability, balance, flexibility and a stable life perspective (Wagnild \& Young, 1993).In our study we can observe that in both factors of the resilience variable the sample mean was high. In the Self/Life Acceptance we had an average of 5.95 points with a standard deviation of 0.604. In the personal competence factor, the result was similar with a mean of 5.98 and with a standard deviation of 0.705.Baltes and Baltes (1993) evaluated the processes of selection, optimization and compensation (SOC) through self-report, seeking to test the prediction of subjective indicators of successful aging. In the case of the elderly evaluated in this study, the total SOC mean obtained was 7.89 (Table 1), which can be considered adequate since the maximum score is 12 . This model is divided into four strategies: elective selection, selection based on loss, optimization and compensation. In all strategies, the score can vary from 0 to 3 . We can see in table 3 that the strategy most used is the loss-based selection that obtained the highest average.

Table 3. SOC model strategies

\begin{tabular}{llllll}
\hline & $\mathrm{N}$ & Min. & Máx. & Mean & $\mathrm{Sd}$ \\
\hline Elective selection & 193 & 0 & 3 & 1,82 & 0,880 \\
Selection for losses & 193 & 0 & 3 & 2,04 & 0,831 \\
Optimization & 193 & 0 & 3 & 1,84 & 0,852 \\
Compensation & 193 & 0 & 3 & 1,89 & 0,894 \\
\hline
\end{tabular}

For the analysis of multiple regression was tested as wisdom dependent variable. Initially, the following independent variables entered the multiple regression model: resilience ("Personal Competence" and "Self/Life Acceptance") and SOC (selection for losses, elective selection, optimization and compensation).After analyzing the linearity and adjustments of the stepwise multiple linear regression model, the following independent variables remained in the final model: resilience and elective selection as we can see in table 4.

Table 4. Multiple linear regression analysis of the dependent variable wisdom

\begin{tabular}{|c|c|c|c|c|c|c|c|}
\hline \multirow{4}{*}{$\begin{array}{l}\text { Model } \\
\qquad \text { (Constant) }\end{array}$} & \multicolumn{7}{|c|}{ UnstandardizedCoefficient } \\
\hline & \multicolumn{2}{|c|}{ s } & \multicolumn{3}{|l|}{ Std. Coef. } & \multicolumn{2}{|c|}{ Statistical colinearity } \\
\hline & B & Std. Error & Beta & $\mathrm{t}$ & Sig. & Toleranc. & VIF \\
\hline & 39,627 & 5,605 & & 7,069 & 0,000 & & \\
\hline Resilience & 0,299 & 0,040 & 0,475 & 7,547 & 0,000 & 0,969 & 1,032 \\
\hline Electiveselection & 1,500 & 0,629 & 0,150 & 2,385 & 0,018 & 0,969 & 1,032 \\
\hline
\end{tabular}

The determination coefficient was $\mathrm{R}^{2}=0.274(\mathrm{p}=0.018)$. Therefore, it is perceived that both resilience and elective selection strategy are necessary for the person to develop wisdom.

\section{Discussion}

In this study, considering the wisdom variable, the participants obtained a high average, and the best performance is in the personality facet. In studies developed by Smith, Dixon and Baltes (1989) five dimensions of wisdom are presented: the first would be full concrete knowledge and full procedural knowledge; the last three would be: to 
understand the contexts of life, to discriminate the differences related to values, to define the goals and priorities and the awareness of the precariousness of knowledge.

It is important to emphasize that this group of scholars has always been interested in observing the practical life, the repertoire that helps to solve problems from excellent strategies, and the reflexive ability that helps in the resolution of difficult and important subjects of real life, favoring the conceptualization of the wisdom from mental development in longevity (Alves, 2011).

Ardelt $(1997,2004)$ argues that some people achieve a sense of completeness and well-being in old age, while others become bitter and lament the decline of their physical abilities and their social role in society. The author asks: what would be the secret to a full and rewarding life in old age? Moreover, she proposes that satisfaction in old age does not depend primarily on the objective situation lived by the elderly, but on psychological development throughout the course of life, especially the level of wisdom.

Although in the studies developed by Baltes, Smith and Staudiger (1992), wisdom has been characterized as a specialized knowledge about the pragmatic foundations of life and more focused on knowledge and cognition, Ardelt (2004) considers wisdom as an integration of characteristics of personality: cognitive, reflexive and affective. This data confers on the result of the present study, since the most punctuated facet was that of personality and the wisdom score of the studied population was high.

Another aspect that confirms the results obtained is that unlike cognition, wisdom is not expected to decline with advancing age. On the contrary, wisdom has been associated with society elderly population (Assmann, 1994; Baltes\& Smith, 2004).

Baltes and Staudiger (2000) also report that for the development of wisdom it is important that people integrate the cognitive, motivational, social, interpersonal and spiritual characteristics in a harmonious way; point out that wisdom integrates skills related to the processes of selection, optimization and compensation in a clear reference and relation to successful aging. In this way, wisdom would be a precious element to help promote human excellence in the conduct of life, since it would allow the identification of strategies and goals formed from lifeknowledge and oriented towards individual and social well-being.

Analyzing the fact that the elderly participants in this study were autonomous and independent, not being institutionalized, it is possible to have an explanation for the high index of resilience evidenced. Rabelo and Neri (2006) explain that the elderly can present great capacity for resilience, because in the face of losses they tend to reorganize their environment in a way that maximizes the positive effects and minimizes the negative ones. In addition, it is confirmed that resilience can be a mechanism that helps individuals to overcome and adapt to the negative changes that occur during the aging process (Windle, Woods, \& Markland, 2010).

As in this study, in relation to gender and its relation to resilience, Fontes, Portuguez and Argimon (2009) and Cardoso (2014) observed that women present a higher mean in the resilience scale, found a significant difference. Considering the two aspects of resilience "self acceptance" and "personal competence" there was no significant difference between them. These results can be justified by the fact that the two facets can act as a coping mechanism that contributes to the adaptation of elderly individuals to the challenges and losses inherent to the aging process, allowing a greater adaptation to the reality where they are inserted (Silva, Farias, Oliveira, \& Rabelo, 2012).

Regarding the score obtained by the participants in the SOC strategies, the score identified was above average. Baltes and Smith (2004) affirm that the SOC model is a psychosocial construct and its expression reaches its peak in adulthood, accentuating itself in aging as a plan of selection and compensation with specific personal and contextual characteristics, being therefore the result obtained within the expected for this population.

In relation to the selection resource used by the elderly to reach a successful aging, authors such as Freund and Baltes (2002) as well as Bajor and Baltes (2003) distinguished the selection based on losses and the elective. In the study presented here, it can be observed that the selection based on losses obtained a higher average than the elective one. This fact can be explained because the selection for losses was for this generation of elderly people reinforced over time. Not having the opportunity to develop both elective selection, which would be more expected for an aging marked by autonomy.

However, in the regression model presented in our study we found the association of resilience and elective selection as predictors of wisdom. These results indicate that personality traits relate to how individuals adapt to life events (Maiden, Peterson, \& Caya, 2003), where resilience works as a protective factor helping individuals to adapt to change that occur in their lives (Lü, Wang, Liu, \& Zhang, 2014). To accomplish these changes, the participants of this study use elective selection strategy. 


\section{Conclusions}

With the growing number of elderly people in the society, it becomes relevant to understand factors that intervene in the aging process. To achieve this challenge, it is necessary that several aspects be observed in several areas of life. It is known that losses are also inevitable, but the way the elderly face them and what strategies they adopt will help to understand this process. Personality, resilience, and attitudes toward aging influence, the way older people deal with situations and the changes that occur in life, and can protect the individual from adversity and contribute to the success of aging. The results of this study allowed us to verify that in the studied population the variable wisdom scored high index, emphasizing the personality facet, the same occurred with the variables resilience and SOC, there being no significant difference between men and women and between different age groups. In addition, it was observed that for the population studied, strategies of resilience and elective selection are predictors of wisdom. The successful aging literature calls resilience one of the seven propositions for successful aging, just as elective selection is one of the strategies for successful aging. Therefore, it is understood that wisdom has a greater chance of developing during old age when it is marked by a successful aging process. The present study, however, have some limitations. The sample consisted only of autonomous and non-hospitalized elderly, which does not represent the total of the elderly population of the city of Ivoti / RS. Culturally the population also presents specific characteristics of the German colonization in the state and for this reason one cannot make generalizations regarding other populations of the elderly. Despite the limitations indicated, the present study may contribute to the understanding of the aging process, namely in relation to the influence of wisdom and resilience in the aging process.

\section{References}

Aldwin, C. M, \& Gilmer, D. F. (2004). Health, Illness, and Optimal Aging: Biological and Psychological Perspectives. California: Sage Publications.

Almeida, S. T., Stobäus, C. D., \& Resende, T. L. (2013) Adaptação transcultural do Selection, OptimizationandCompensationquestionnaire (SOC) para aplicação a idosos. Revista Brasileira de Geriatria e Gerontologia, 16(2), 221-237.

Alves, P. (2011).A sabedoria: definição, multidimensionalidade e avalição. Lisboa, Instituto Piaget.

Ardelt, M. (1997). Wisdom and life satisfaction in old age. Journal of gerontology:Psychological sciences, 52B, (1), 15-27. Recuperado de: http://web.clas.ufl.edu/users/ardelt/Wisdom_and_life_satisfaction_in_old_age.pdf.

Ardelt, M. (2004) Wisdom as expert knowledge system: a critical review of a contemporary operationalization of an ancient concept. Human Development., 47, 257-285. Recuperado de: http://www.clas.ufl.edu/users/ardelt/Wisdom\%20as\%20expert\%20knowledge\%20system.pdf.

Assis, S. G., Avanci, J.Q., Pesce, R.P., \&Deslandes, S.F. (2006). Superação de dificuldades na infância e adolescência: conversando com profissionais de saúde sobre resiliência e promoção da saúde. Rio de Janeiro: FIOCRUZ/ENSP/CLAVES/CNPq.

Assmann, A. (1994). Wholesome knowledge: Concepts of wisdom in a historical and cross-cultural perspective. In D.L. Featherman, R.M. Lerner, \&M. Perlmutter(Eds.), Life-span developmentand behavior (pp. 187-224). London: Sage.

Bajor, J. K., \&Baltes, B. B. (2003). The relationship between selection optimization with compensation, conscientiousness, motivation, and performance. Journal of Vocational Behavior, 63(3), 347-367.

Baltes, P. B., Smith, J., \& Staudinger, U. M.(1992). Wisdom and successful aging. In T. Sonderegger (Ed.),Nebraska Symposium on Motivation (pp. 123-167). Lincoln: University of Nebraska Press.

Baltes,P. B., \&Baltes M. M. (1993). Successful aging: perspectives from behavioral sciences. Cambridge: Cambridge University.

Baltes, P.,\&Staudiger, U. (1993). The search for a psychology of wisdom. Current directions in Psychological Science, 2, 75-80.

Baltes, P.,\&Staudiger, U. (2000). Wisdom: a metaheuristic (pragmatic) to orchestrate mind and virtue toward excellence. American Psychologist, 55 (1),122-136.

Baltes, P., \& Smith, J. (2004). Psychology: from developmental contextualism to developmental biocultural coconstructivism. Research in HumanDevelopment, 1(3), 123-144.

Baltes, P., \& Smith,J. (1995). Psicologia da sabedoria: origem e desenvolvimento. In A. Neri (Org.). Psicologia do envelhecimento(pp. 41-72). Campinas: Papirus.

Baltes, P. B., \& Smith, J. (2004). Lifespan Psychology: from developmental contextualism to developmental biocultural co-construtivism. Research in Human development,1(3), 123-144. Retrieved from http://www.tandfonline.com/doi/abs/10.1207/s15427617rhd0103_1\#.U0NbNvldV1Y 
Baltes, P. B., \&Baltes, M. M. (1993). Successful aging: perspectives from the behavioral sciences. Cambridge: Cambridge University Press.

Baltes, P. B. (1987). Theoretical propositions of the lifespan developmental psychology: on the dynamics between growth and decline.Developmental Psychology, 23(5), 611-696.

Baltes, P. B., \& Mayer, K. U. (2001).The Berlin Aging Study: aging from 70 to 100. Berlin: Cambridge: Cambridge University.

Baltes, P., \&Staudiger, U. (2000). Wisdom: a metaheuristic (pragmatic) to orchestrate mind and virtue toward excellence. American Psychologist, 55 (1), 122-136.

Baltes, P. B., \&Silverberg, S. (1995). A dinâmica dependência-autonomia no curso de vida. In A. L. Neri (Org.),Psicologia do envelhecimento(pp. 73-110). São Paulo: Papirus Editora.

Bandura, A. (1986). Social foundation of thought and action: A social cognitive theory. EnglewoodCliffs, Nova Jersey: Prentice Hall.

Barros, J. (2005). Psicologia do envelhecimento e do idoso. Porto: Livpsic.

Berkman, L. F., Seeman, T. E., Albert, M., Blazer, D., Kahn, R., Mohs, R.; Finch, C., Schneider, E., Cotman, C., \&Mcclearn, G. (1993) Successful, usual, and impaired functioning in community dwelling elderly: Findings from the MacArthur Foundation Research Network on Successful Aging. JournalofClinicalEpidemiology, 46(10) 1129-1140.

Cardoso, A. H. (2014). Suporte Social, Esperança, Otimismo e Frequência da Universidade Sénior - Fatores de Resiliência na Terceira Idade? (Dissertação de Mestrado). Universidade do Algarve, Portugal. Retrieved from https://sapientia.ualg.pt/handle/10400.1/7915.

Carr, A. (2007). Psicología positiva. La ciência de la felicidad.Barcelona: Paidós.

Coelho Filho, J. M.,\& Ramos, L. R.(1999). Epidemiologia do envelhecimento no Nordeste do Brasil: resultados de inquérito domiciliar. Rev. Saúde Pública, 33 (5), 445-453.

Couto, M. C. (2007). Fatores de risco e de proteção na promoção de resiliência no envelhecimento (Dissertação de Mestrado) Pós Graduação em Psicologia, UFRGS, Porto Alegre.

Coll, C., Palácios, J., \&Marchesi, A.(2004). Desenvolvimento psicológico e educação. Porto Alegre: Artes Médicas.

Erikson, E. (1998). O ciclo de vida completo. Porto Alegre: Artmed.

Fortes, T., Portuguez, M., \&Argimon, I. (2009). A resiliência em idosos e sua relação com variáveis sociodemográficas e funções cognitivas. Estudos de Psicologia, 26(4), 455-463. Retrieved from http://www.scielo.br/scielo.php?script=sci_arttext\&pid=S0103166X2009000400006\&lng=pt\&nrm=iso\&tlng= pt.

Freund, A. M., \&Baltes, P. B. (2002). Life-management strategies of selection, optimization, and compensation: measurement by self-report and construct validity. Journal of Personality and Social Psychology, 82(4), 642662.

Gatz, M. (1998). Towards a developmentally-informed theory of mental disorder in older adults. In J.Lomranz (Org.),Handbook of aging and mental health(pp.101-120).New York: Plenum.

Gois, I. B., Silva-Mann, R., \& Ferreira, R. A. (2009).Diversidade genética de indivíduos de Spondiaslutea L., por meio de isoenzimas. ScientiaForestalis, 37, 55-60.

Lü, W., Wang, Z., Liu, Y., \& Zhang, H. (2014). Resilience as a mediator between extraversion, neuroticism and happiness, PA and NA. Personality and Individual Differences, 63, 128-133.

Maiden, R. J., Peterson, S. A., \&Caya, M. (2003). Personality changes in the old-old: A longitudinal study. Journal of Adult Development, 10(1), 31-39.

Moraes, J., \& Souza, V. (2005). Factors associated with the successful aging of the socially-active elderly in the metropolitan region of Porto Alegre. Revista Brasileira de Psiquiatria,27(4), 302-308.

Neri, A. L. (2013). Fragilidade e qualidade de vida na velhice.Campinas: Alínea.

Neri, A. L., \&Cachioni, M. (1999). Velhice bem-sucedida e educação. In A. L. Neri, \& G. G. Debert (Orgs.), Velhice e sociedade(pp. 113-140). São Paulo: Papirus Editora.

Neri, A., Yassuda, M.; \&Ciachioni, M. (2004). Velhice bem-sucedida: aspectos afetivos e cognitivos. Campinas: Papirus.

Neri, A. (2002). Teorias psicológicas do envelhecimento. In E. Freitas, L. Py, A. L. Neri (Orgs.), Tratado de Geriatria e Gerontologia(pp.32-46).Rio de Janeiro: Guanabara-Koogan.

Neri, A. L., \& Fortes, A. C. G. (2006). A dinâmica do estresse e enfrentamento na velhice e sua expressão no prestar cuidados a idosos no contexto da família. In E. Freitas et al. (Eds). Tratado de Geriatria e Gerontologia (pp. 1277-1288). Rio de Janeiro: Guanabara Koogan. 
Oser, F., Schenker, D. E., \&Spychiger, M. (1999). Wisdom: an action oriented approach. In K. Reich, F. Oser, \&W. Scarlett (Orgs.),Psychological studies on spiritual and religious development: being human: The case of religion (pp. 155-172).Lengerich: PabstSciencePublishers.

Ospina Muñoz, D. E. (2007). La medición de la resiliencia. Measurement of resilience. Investigación y Educación en Enfermería, 25(1), 58-65. Retrieved fromhttp://www.scielo.org.co/ scielo.php?pid=S0 12053072007000100 006 \&script=sci_arttext

Papalia, D., \&Feldman, R. (2013). Desenvolvimento Humano. Porto Alegre: Artmed.

Pesce, R., Assis, S., Avanci, J., Santos, N., Malaquias, J., \& Carvalhaes, R. (2005). Adaptação transcultural, confiabilidade e validade da escala de resiliência. Caderno de Saúde Pública, 21 (2), 436-448.

Pascual-Leone,J.(1990). An essay on wisdom: toward organismic processes that make it possible. InR. Sternberg. (Org.), Wisdom: its nature, origins, and development (pp. 224-278). Nova Iorque: Cambridge University Press.

Rabelo, D. F. E., \& Neri, A. L. (2006). Bem-estar subjetivo e senso de ajustamento psicológico em idosos que sofreram Acidente Vascular Cerebral: Revisão. Estudos de Psicologia, 11(2),169-17.

Rowe, J. W., \& Kahn, R. L. (1998). Successful aging. New York: Pantheon Books.

Silva, L., Farias, L., Oliveira, T., \& Rabelo, D. (2012). Atitude de idosos em relação à velhice e bem-estar psicológico. RevistaKairósGerontologia, 15(2), 119-140.

Smith, J., Dixon, R., \&Baltes, P. (2008). Expertise in Life planning: a new research approach to investigating aspects of wisdom. InM. Commons, F. Sinnot, U. Staudinger (Orgs.),A psychology of wisdom: history and recent developments. Retrieved from: http://www.tandfonline.com/doi/ab s/10.1080/1542760080 2034835\#.U0 N hqPld V1Y.

Staudinger, U. (2008). A psychology of wisdom: history and recent developments. Research in Human Development, 5 (2), 107-120.

Sternberg, R. (1990). Wisdom: its nature, origins, and development. Nova Iorque, Cambridge University Press.

Sternberg, R.(2004). Words to the wise about wisdom? Human Development, 47 (5), 286-289.

Strawbridge, W. J., Cohen, R. D., Shema, S. J., \& Kaplan, G. K. (1996). Successful aging: Predictors and associated activities. Research on Aging,21, 402-416.

Wagnild, G. M. (2009). The Resilience Scale User's Guide for the US English version of the Resilience Scale and the 14-Item Resilience Scale.New York, University Press.

Wagnild, G. M., \& Young, H. M. (1993). Development and psychometric evaluation of the resilience scale. Journal of Nursing Measurement, 1(2), 165-177.

Windle, G., Woods, R., \& Markland, D. (2010). Living with ill-health in older age: The role of a resilient personality. Journal of Happiness Studies, 11(6), 763-777.

Wosiack, R. M. R., Berlim, C. S., \& Santos, G. A. (2013). Fatores de risco e de proteção evidenciados em idosos moradores da cidade de Ivoti/RS: intervenções psicossociais na área da gerontologia. Revista Brasileira de Ciências do Envelhecimento Humano, 10 (3), 256-270. 